\title{
The ultrasonic processing of dairy products - An overview
}

\author{
Muthupandian AshoKkumar ${ }^{1 *}$, Raman Bhaskaracharya ${ }^{1}$, Sandra Kentish ${ }^{1}$, \\ Judy LeE ${ }^{1}$, Martin PALmer ${ }^{2}$, Bogdan Zisu ${ }^{2}$ \\ ${ }^{1}$ School of Chemistry/Department of Chemical and Biomolecular Engineering, University of Melbourne, \\ VIC 3010, Australia \\ ${ }^{2}$ Dairy Innovation Australia Ltd., 671 Sneydes Road, Werribee, VIC 3030, Australia
}

\begin{abstract}
Received 23 March 2009 - Revised 21 September 2009 - Accepted 22 September 2009
\end{abstract}
Published online 10 November 2009

\begin{abstract}
Ultrasonic processing is an emerging technology in food processing. When ultrasound passes through a liquid, bubble nuclei present in the liquid grow by bubble coalescence and rectified diffusion. When these bubbles reach a critical size range, they collapse under nearadiabatic conditions generating extreme conditions within the bubbles and in the surrounding liquid that include intense shear forces, turbulence and microstreaming effects. These ultrasound-induced physical effects are finding increasing use in food and dairy processing, in applications such as the enhancement of whey ultrafiltration, extraction of functional foods, reduction of product viscosity, homogenization of milk fat globules, crystallization of ice and lactose and the cutting of cheese blocks. After a brief introduction to the ultrasonic processing of food systems in general, this review presents a critical discussion of applications in dairy processing, together with the findings of some recent research on the use of ultrasound to modify the functionality of dairy protein ingredients.
\end{abstract}

ultrasonic processing / acoustic cavitation / whey protein / dairy product

摘要 - 乳品加工中的超声处理一一综述。摘要 超声处理是食品加工中的新技术。当超声 波穿透液体时, 由于气泡合并使得液体中的气核逐渐长大, 当这些气泡长到一定程度时, 在 气泡内部形成了接近绝热的极端环境, 这时气泡破裂对周围液体产生了极大的冲击力, 并起 到强烈的搅拌作用, 同时生成了大量的微泡。超声波对食品和乳制品产生的物理作用引起 了人们的关注, 如超声波可以提高乳清超滤效果、用于功能性食品成分的提取、降低产品 的粘度、乳脂肪球的均质、冰和乳糖和的结晶以及干酪的切割等。本文结合超声技术在功 能性乳蛋白成分提取中的最新研究成果, 重点讨论了超声技术在乳制品中的应用。

\section{超声处理 / 声波的空穴 / 乳清蛋白 / 乳制品}

Résumé - Traitement par ultrasons des produits laitiers - une revue. Le traitement par ultrasons est une technologie émergente dans l'industrie alimentaire. Quand les ultrasons passent au travers d'un liquide, les micro-bulles présentes dans le liquide grossissent par coalescence et diffusion rectifiée. Quand ces bulles atteignent la gamme de tailles critiques, elles se dégonflent sous des conditions adiabatiques générant des conditions extrêmes à l'intérieur des bulles et dans le liquide environnant telles que forces de cisaillement intenses, turbulence et micro-ruissellement. Ces effets physiques induits par les ultrasons sont en train de trouver de plus en plus d'usage dans

*Corresponding author (通讯作者): masho@unimelb.edu.au 
l'industrie alimentaire et laitière, dans des applications telles que l'amélioration de l'ultrafiltration du lactosérum, l'extraction d'aliments fonctionnels, la réduction de la viscosité des produits, l'homogénéisation des globules gras du lait, la cristallisation de la glace et du lactose et le découpage des blocs de fromage. Après une brève introduction sur le traitement par ultrasons des systèmes alimentaires en général, cette revue présente une discussion critique des applications en technologie laitière, ainsi que les résultats de certaines recherches récentes sur l'usage des ultrasons pour modifier les fonctionnalités des ingrédients protéiques laitiers.

\section{ultrason / cavitation acoustique / protéine de lactosérum / produit laitier}

\section{INTRODUCTION}

In addition to traditional methods such as heat treatment, mechanical agitation, drying and freezing, a variety of new technologies are now available to enhance the processing efficiency, shelf-life, safety and functional properties of dairy products and other processed foods and food ingredients. Among various "emerging technologies" such as ultra-high pressure processing, pulsed electric fields, supercritical fluid extraction, microfluidization and ultraviolet light treatment, ultrasonication has been identified as a particularly promising technology for processing specific food materials, including dairy products [24, 64, 97]. Most studies to date have been carried out in a batch mode where small volumes of the solutions are sonicated in laboratory-scale vessels for a defined period of time. However, efficient large-scale continuous flow-through ultrasonic systems have become increasingly available over the last decade. In these systems, the solution is pumped continuously through a vessel containing a sonicating device. The availability of these systems has facilitated this technology to move from the laboratory into fully operational commercial food processes throughout Europe and the USA [81]. Ultrasonic processing is establishing itself as a significant food-processing technology with the capability for large commercial scale-up operation and good payback on capital investment [81].

The use of ultrasound in food and dairy processing in general has been discussed in a number of review articles $[24,49,64,66$, 82, 93]. Mason et al. [64] have suggested that the mechanical and chemical effects generated by low-frequency - high-intensity ultrasound may be useful for inactivating pathogens in food products and enhancing extraction and emulsification processes. Villamiel et al. [93] similarly have focused on the microbial effects of ultrasound in dairy systems but also described cleaning applications. Mawson and Knoerzer [66] have provided a brief history of the applications of ultrasound in food processing in general, including examples of well-established applications such as cleaning of processing equipment, together with newer proposed applications such as enhancement of the extraction of food ingredients from natural products [6, 13, 87]. Knorr et al. [49] have also reviewed the applications and potential of ultrasonics in food processing, focusing particularly on uses related to food preservation and food quality parameters. Patist and Bates [81] provide a summary of the key drivers for the deployment of ultrasonic technology into commercial production.

This review will first provide a short introduction to acoustic cavitation and the broad principles of ultrasonic processing. A detailed account is then presented of the use to date of ultrasound technology in dairy processing, including the results of some recent research on the use of ultrasound to modify the functionality of dairy protein ingredients.

\subsection{Ultrasound and acoustic cavitation}

Ultrasound refers to sound waves above the frequency of human hearing $(\sim>18 \mathrm{kHz})$. When high-intensity 


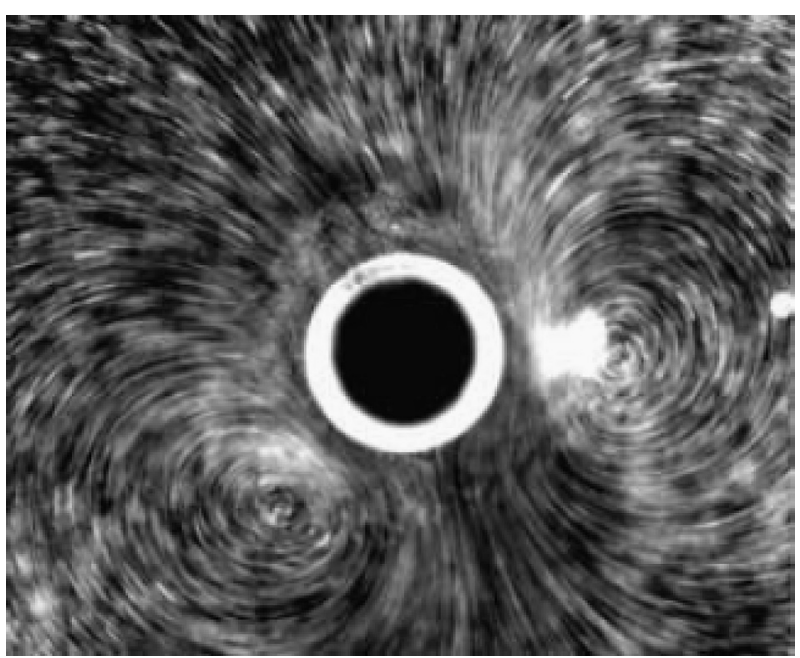

Figure 1. Acoustic streaming patterns around a $272 \mu \mathrm{m}$ radius bubble excited at $4 \mathrm{kHz}$. (Reprinted with permission from [91].)

ultrasound is passed through a medium, strong vibration of the medium occurs. If the medium contains solid particles, for example, plant materials such as seeds, severe structural damage of these particles can occur. Such mechanical vibration effects can be used in cleaning and extraction applications. In addition to the mechanical vibration effect, ultrasound also generates acoustic streaming within liquids [91], as shown in Figure 1, which can increase effective mass transfer leading to enhanced cleaning and extraction efficiencies in some industrial processes.

However, in most ultrasonic processing applications, the observed effects are due to acoustic cavitation [10], which involves the growth and collapse of pre-existing microbubbles in liquids. Gas microbubbles in liquids, if in a suitable size range [101], begin to oscillate in diameter when subjected to ultrasound. When the applied acoustic energy exceeds the cavitation threshold, the oscillation of gas bubbles becomes intense leading either to transient or stable (repetitive transient) cavitation [10].

In transient cavitation, observed primarily with horn-type sonicators operated at $20 \mathrm{kHz}$ and high acoustic intensities, bubble growth occurs within a few acoustic cycles leading into their resonance size range [101], where the bubbles rapidly collapse (see Fig. 2a). The bubbles disintegrate into fragments due to the violent nature of the collapse. In stable cavitation however, bubble growth occurs over thousands of acoustic cycles either by rectified diffusion and/or bubble coalescence pathways [8]. Stable cavitation is commonly observed at high $(>200 \mathrm{kHz}$ ) ultrasound frequencies. Once the bubbles reach a resonance size range [101], they collapse like transient bubbles; however, the collapse is less violent and hence the bubbles may grow and collapse continuously (Fig. 2b).

The combined effects of mechanical vibration, acoustic streaming and cavitation can enhance mass transfer and hence reaction rates and extraction efficiencies. The non-cavitational physical effects (mechanical vibration and acoustic streaming) and cavitational physical effects (shear forces, shock waves, microjets, etc.) of ultrasound have been used for a number of applications that include emulsification, extraction, cleaning and welding $[6,13,29,38,48$, 

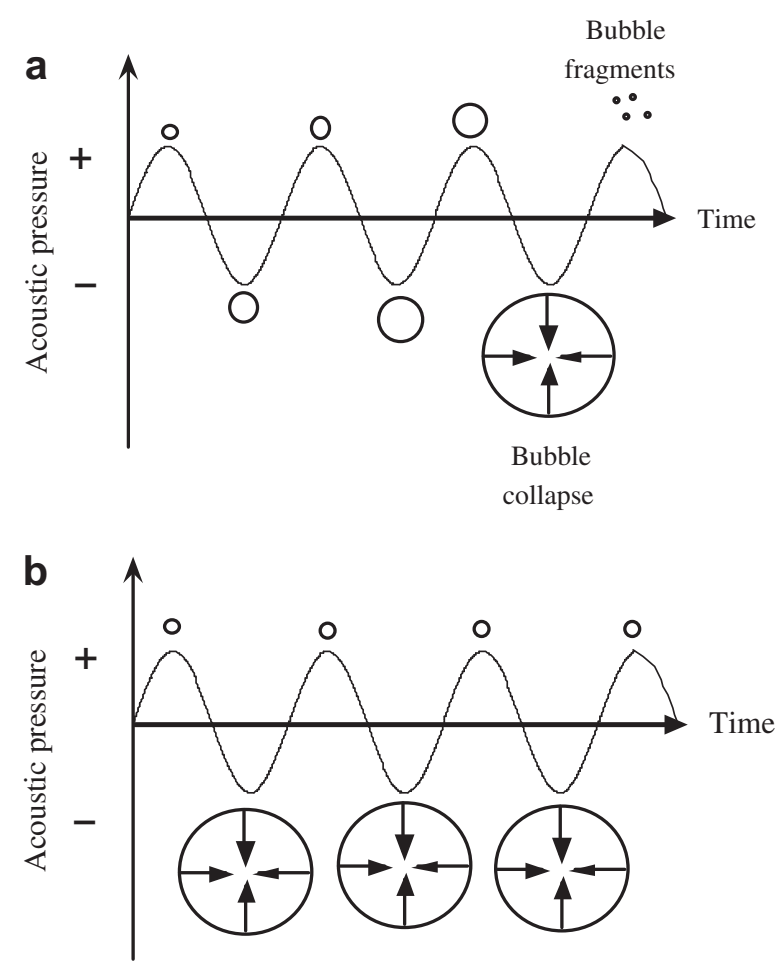

Figure 2. Schematic representation: (a) transient cavitations and (b) stable cavitations.

$62,80,83]$. The collapse of cavitation bubbles (both transient and stable) also leads to the generation of high temperatures and pressures within the collapsing bubbles. This is due to the fact that the collapse occurs in a very short time $(<1 \mu \mathrm{s})$ leading to near-adiabatic heating of the bubble interior. Experiments have suggested that the temperatures generated within the cavitation bubbles are in the range 2000-5000 K [10].

In aqueous solutions, the interior of the cavitation bubbles is filled with water vapor and gas molecules, such as $\mathrm{N}_{2}$ and $\mathrm{O}_{2}$ (in airsaturated water) that diffuse into the bubbles during bubble oscillations in the growth phase. When subjected to the high temperature conditions generated during bubble collapse, the solvent and gas molecules undergo "endothermic" chemical reactions leading to the generation of a variety of highly reactive radicals. In aqueous solutions, it can be expected that the majority of the bubble content is water vapor (since water is a solvent). The homolytic cleavage of water molecules leads to the formation of $\mathrm{OH}^{\circ}$ and $\mathrm{H}^{\prime}$ radicals. Other reactive species are also generated by the reaction of primary radicals with gaseous species such as $\mathrm{N}_{2}$ and $\mathrm{O}_{2}$ and solutes that are present in the solution. These chemical effects have been used in conjunction with the physical effects of ultrasound for achieving a number of useful chemical reactions such as the synthesis of nanomaterials with specific optical properties and the synthesis of protein microspheres that can be used as ultrasound contrast agents [10]. However, the generation of $\mathrm{OH}^{\prime}$ radicals may also reduce the antioxidant capacity of a food product [11]. The addition of a free radical scavenger such 
as ascorbic acid [41] may prove useful in limiting these reactions.

In general, acoustic cavitation at low frequencies $(\sim 20 \mathrm{kHz})$ generates strong physical forces (shear, turbulence, etc.). The amount of reactive radicals generated is very low [10]. Higher frequency acoustic cavitation $(300-500 \mathrm{kHz})$ generates relatively weaker physical effects and significantly larger amounts of chemically active radicals. Frequencies above $1 \mathrm{MHz}$ are generally useful for non-destructive imaging purposes. However, these high frequencies have also been found to be most appropriate for the generation of fine aerosols from a free liquid surface, in a process referred to as ultrasonic nebulization [45].

The choice of frequency for specific applications is based on the requirement for physical or chemical or a combination of both effects. For example, for emulsion polymerization reactions, strong shear forces and a reasonable number of primary radicals are required. However, for applications such as extraction and cleaning, primarily physical effects are required. In food- and dairy processing applications, low-frequency ultrasound is preferred since the physical effects are stronger and radical production/reaction is insignificant. Similarly, a short time exposure to ultrasound is preferred. Aside from the energy efficiency of a short exposure, Riener et al. [84] showed that extended sonication of milk could generate a range of volatile organic compounds that might be responsible for a "rubbery" aroma. They related these compounds to both pyrolysis reactions inside the cavitating bubbles and to free radical-induced lipid oxidation resulting from the decomposition of unsaturated fatty acid hydroperoxides.

\section{ULTRASOUND IN DAIRY PROCESSING APPLICATIONS}

Ultrasound has already made significant inroads into commercial dairy processing operations. Probably the most significant application in this respect is the use of ultrasonic cutting devices. These machines utilize the high-frequency acoustic vibrations $(20-35 \mathrm{kHz})$ to provide a smooth and clean cut for both hard and soft cheeses, minimizing wastage $[4,5,56]$. Ultrasound has also been commercialized as a method of sealing milk containers and packages of grated cheese - in a process also referred to as ultrasonic welding, the temperature induced by the cavitation processes described above is sufficient to seal the plastic $[38,83]$.

\subsection{Ultrasonic imaging}

There are numerous examples of the use of ultrasound as a non-invasive analytical tool in dairy research and analysis $[2,12$, 14-19, 26, 30, 34, 37, 55, 69, 70, 98]. Changes in the velocity and amplitude of the acoustic wave as high-frequency $(>1 \mathrm{MHz})$ ultrasound is passed through a sample provide accurate information on the elastic properties of a material [55]. For example, Corredig et al. [30] used ultrasonic spectroscopy to monitor the gelation of milk components. This involved the measurement of the velocity and the attenuation of the ultrasonic amplitude at different frequencies in the processed samples. Wang et al. [98] used low-intensity ultrasound to assess the renneting properties of casein solutions after heat treatment. Ultrasonic imaging has also been used to study structure development in various cheeses [17, 18], cut-time in cheese making [37], the rheological properties of cheese [55], structural changes in cheese due to heating [69] and cheese maturity [15].

\subsection{Ultrasonic degassing, homogenization and emulsion formation}

The foaming of dairy solutions during processing can reduce the final product 


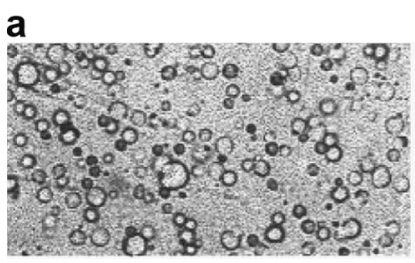

b

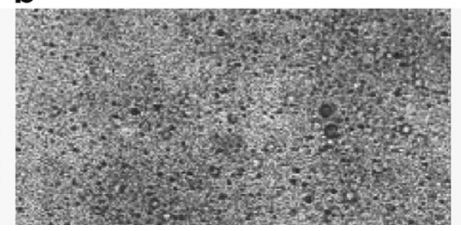

C

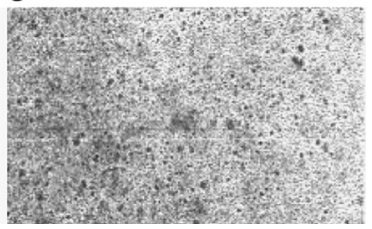

Figure 3. Micrographs of milk samples: (a) without homogenization (average size of fat globules $\sim 4-7 \mu \mathrm{m}$ ), (b) ultrasonic homogenization at $90 \mathrm{~W}$ for $10 \mathrm{~min}$ (average size of fat globules $\sim 2 \mu \mathrm{m}$ ) and (c) ultrasonic homogenization at $450 \mathrm{~W}$ for $5 \mathrm{~min}$ (average size of fat globules $<1 \mu \mathrm{m}$ ). (Adapted from Figure 1 of [33].)

yield and may accelerate oxidative degradation. Villamiel et al. [94] used $20 \mathrm{kHz}$ pulsed ultrasound to degas reconstituted skim milk. While gas bubbles were easily removed in $<5 \mathrm{~min}$ of sonication, the dissolved oxygen content could not be significantly reduced even after $20 \mathrm{~min}$. More recently, Riera et al. [85] have shown that airborne ultrasound can be an effective approach to foam minimization.

The preparation of very fine emulsions is of increasing interest to the beverage and food ingredients industry, as this can permit novel oil-soluble ingredients to be added to water-based products with negligible impact on solution clarity and stability. Lowfrequency ultrasound has been effectively used for the preparation of such food emulsions. A particular advantage of the ultrasonic approach is the ease of equipment cleaning relative to traditional homogenizers or the newer microfluidic devices. This assists in the maintenance of an aseptic environment. Jafari et al. [43] compared the emulsification efficiencies of ultrasonic and microfluidization techniques. An oil-inwater nanoemulsion of d-limonene was prepared using a $24 \mathrm{kHz}$ horn-type sonicator and the size range of the emulsion droplets was compared with that prepared using an air-driven microfluidizer operating at 20-124 MPa. Both techniques were found to generate emulsion droplets in the size range 150-700 nm; however, the ultrasonic method was found to be better in terms of operation and cleaning. Our own analysis of the energy requirements suggests that ultrasound may be a more cost-effective processing option than microfluidization [48]. However, other workers [93] suggest that ultrasonic homogenization is more energy intensive leading to higher costs.

Ertugay et al. [33] studied the ultrasonic homogenization of milk at $20 \mathrm{kHz}$ and compared the results with those of a conventional homogenizer. The size distribution of the fat globules after the conventional homogenization process (at 200 bar and $55^{\circ} \mathrm{C}$ ) was about 2-5 $\mu \mathrm{m}$. However, as can be seen in Figure 3, the size range of fat globules in ultrasonically homogenized milk samples was much smaller. The mean size and size distribution of the fat globules were dependent on the ultrasonic power and length of sonication (Fig. 3). They attributed the observed smaller size of fat globules to the physical effects generated during acoustic cavitation.

Wu et al. [100] also observed similar ultrasonic homogenization effects on fat globules in milk. They observed that the fermentation time of the ultrasonically homogenized milk to form yogurt was significantly reduced due to sonication increasing enzyme activity. In addition, reduced syneresis and improved viscosity of the yogurt were also observed. These latter effects were attributed to increases in the water-retaining casein 
becoming available as the fat globule membrane surface area increased.

Bermúdez-Aguirre et al. [22] studied the changes to the microstructure of fat globules in whole milk following thermosonication treatment. The sonication $(24 \mathrm{kHz}, 400 \mathrm{~W}$ and $30 \mathrm{~min}$ ) of whole milk at high temperatures $\left(63{ }^{\circ} \mathrm{C}\right)$ resulted in fat globules of $<1 \mu \mathrm{m}$ with more binding sites on the fat globule membrane favoring the amalgamation of casein and serum proteins, and thus producing an ideal ingredient for cheese making. The authors suggested that the observed changes were due to cavitation since heat treatment alone did not show similar changes to the fat globules. Vercet et al. [96] studied the rheological properties of the yogurt made from milk subjected to thermosonication. The texture and firmness of the yogurt were significantly improved by the thermosonication procedure.

\subsection{Membrane flux enhancement and milk fouling}

Fouling of ultrafiltration membranes is a major issue affecting the cost and efficiency of many dairy manufacturing operations. During the filtration of processed milk and its constituents, a build-up of particles occurs on the filtration membranes leading to membrane fouling, and ultimately reduced throughput in large-scale processing. A detailed discussion on the parameters that affect fouling of ultrafiltration membranes is provided by Kentish and coworkers [72].

Kentish and co-workers [73-76] used ultrasound in both the production and cleaning cycles of whey ultrafiltration and found that sonication was effective in both cases. Ultrasound significantly improved membrane cleaning efficiencies. However, it was suggested that the capital and operating costs associated with the application of ultrasound for the membrane cleaning cycle alone are unlikely to be economic. More significantly, ultrasound was effective in improving production flux values by between $40 \%$ and $70 \%$. In Figure 4 , it is shown that the permeate flux was higher for low-frequency operation $(50 \mathrm{kHz}) \mathrm{com}$ pared to that at $1 \mathrm{MHz}$.

The flux rate enhancement during sonication was analyzed using the Ho and Zydney's model [39] for combined cake formation and pore blockage. It was found that the pore blockage parameter was not significantly affected by ultrasound. However, both the initial deposit resistance and cake growth factors were significantly affected by sonication (see Fig. 5).

By considering several reports on the effect of ultrasound on filtration processes $[50-52,54,73,75,76]$, a number of specific effects generated by ultrasonic processing have been noted: (i) sonication can cause agglomeration of fine particles, thus potentially reducing pore blockage and cake compaction; (ii) the turbulence associated with ultrasound can be used to separate physical aggregates of proteins by disrupting the intermolecular forces; (iii) the asymmetric collapse of cavitating bubbles can scour surfaces and this leads to removal or control of the fouling cake layer; and (iv) acoustic streaming and/or cavitation causes turbulence which results in bulk water movement near the membrane surface, which reduces the effects of concentration polarization and thus increases the mass transfer coefficient at the membrane surface.

More generally, ultrasound can be effective in reducing whey protein fouling in processing equipment. Lin and Chen [57] studied the fouling of a heat transfer surface with milk in the presence and absence of ultrasound. Ultrasound was found to be effective in two ways. Firstly, the convective heat transfer coefficient was enhanced which led to a lower heating surface temperature for a constant heat energy input. This lower surface temperature resulted in reduced fouling. Secondly, even when the surface temperature was fixed, fouling was delayed when sonication was used, 


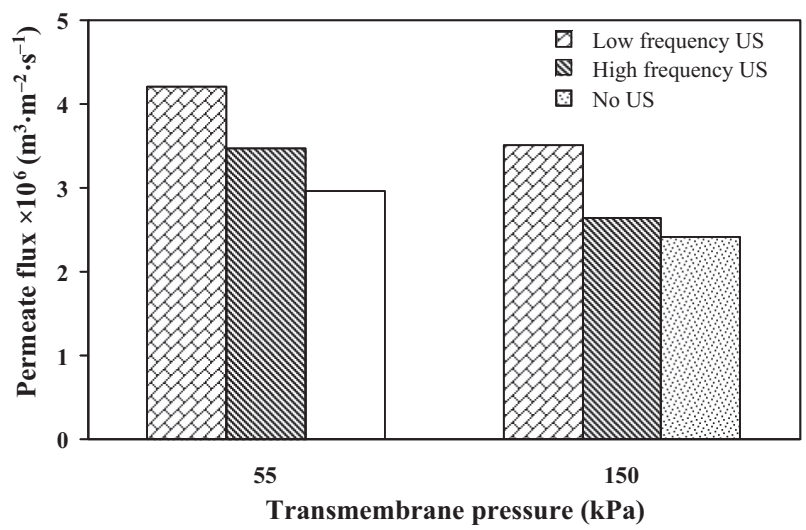

Figure 4. Effect of ultrasonic frequency on whey permeation (cross-flow rate $=550 \mathrm{~mL} \cdot \mathrm{min}^{-1}$, $T=20{ }^{\circ} \mathrm{C}, C_{\text {whey }}=6 \%(\mathrm{w} / \mathrm{w})$ and ultrasound power $\left.=300 \mathrm{~W}\right)$. (Adapted from Figure 11 of [72].)
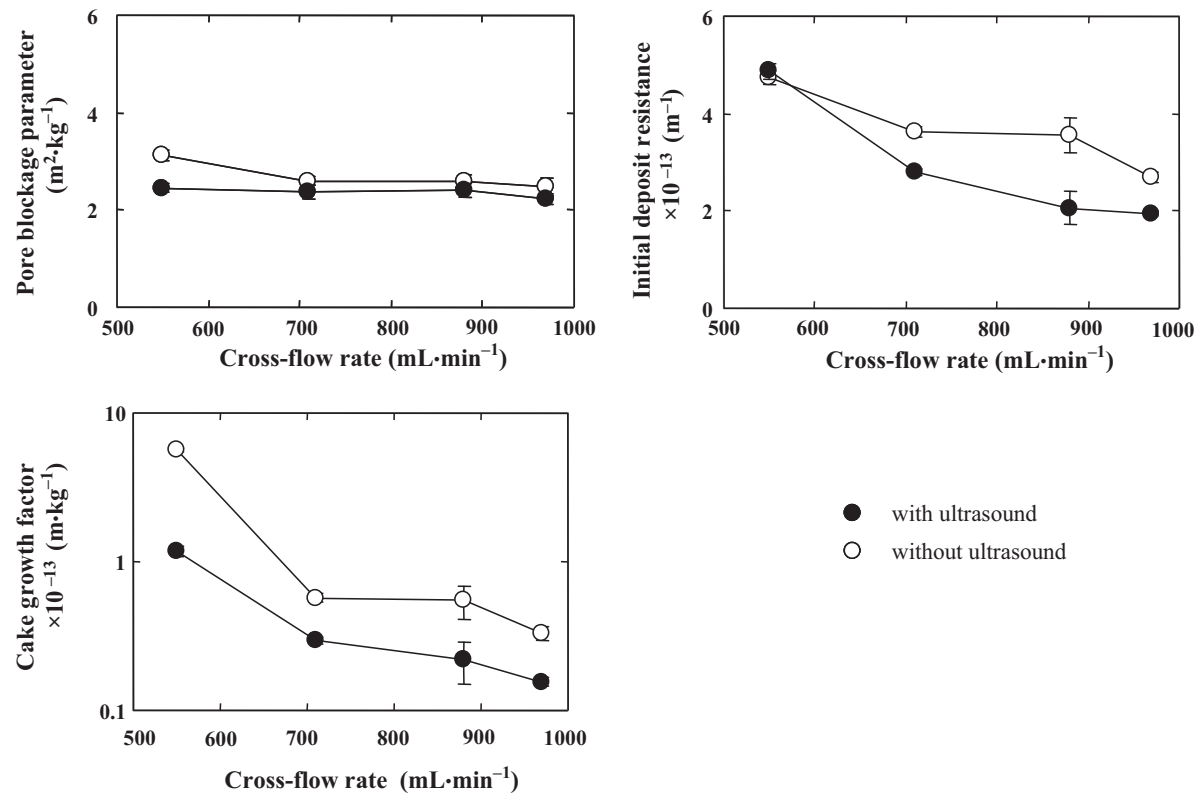

- with ultrasound

- without ultrasound

Figure 5. Best-fit values of the fouling parameters as a function of the cross-flow rate $\left(\mathrm{TMP}=300 \mathrm{kPa}, T=20^{\circ} \mathrm{C}, C_{\text {whey }}=6 \%(\mathrm{w} / \mathrm{w})\right.$ and ultrasound power $\left.=300 \mathrm{~W}\right)$. (Adapted from Figure 8 of [72].)

probably due to scouring and acoustic streaming effects at the surface. Other work- ers have reported the use of ultrasound for cleaning cheese molds $[87,93]$. 


\subsection{Microbial and enzymatic effects}

There has been considerable interest in the potential use of high-power/high-intensity ultrasound, often in conjunction with mild heating (thermosonication) and pressure (manothermosonication) for the inactivation of microbes and enzymes associated with spoilage, safety and quality deterioration in a range of liquid food systems [49, 82].

Vercet et al. [95] found that manothermosonication inactivated both extracellular lipase and protease more effectively than heat treatment alone. Similarly, Barbosa-Cánovas and co-workers $[20,21]$ have shown that the inactivation of Listeria innocua and mesophilic bacteria in raw whole milk is more efficient when thermosonication is used in place of purely thermal pasteurization. Garcia et al. [36] used a combination of heat and ultrasound to examine the survival rate of two strains of Bacillus subtilis in milk. It was observed that the simultaneous use of heat $\left(70-95^{\circ} \mathrm{C}\right)$ and ultrasound $(20 \mathrm{kHz}$, $150 \mathrm{~W}$ ) was more effective in the deactivation process compared to individual treatment by heat or ultrasound alone. The viability of the spores decreased by between $70 \%$ and $99.9 \%$ after the thermosonication process. However, acceptable dairy applications of thermosonication have yet to be commercialized, as the treatment of milk systems with high-intensity ultrasound tends to generate undesirable off-flavors [84].

Conversely, the use of milder levels of ultrasound may yet prove effective in assisting milk fermentation processes. The use of low-intensity ultrasound increases mass transfer within the fermentation vessel and thus can increase enzyme productivity. Sakakibara et al. [86] reported that sonication increased the hydrolysis of lactose in milk in the presence of a starter culture (Lactobacillus delbrueckii) and hence the fermentation process. However, this application of ultrasound also deactivated the cells due to the acoustic cavitation process. Masuzawa and Ohdaira [65] reported that the use of $20 \mathrm{kHz}$ sonication on milk reduced the fermentation time to produce yoghurt. In some very early work, Winder and co-workers $[35,77,99]$ directly attached ultrasonic transducers $(1.2 \mathrm{MHz})$ to cheddar cheese and observed an increase in the cheese ripening time. Ultrasonic treatment of cheese was said to alter the normal sequence of bacterial development and induce the development of abnormally high populations of streptococci, micrococci and lactobacilli. Conversely, Villamiel and de Jong [92] reported that the functional properties of the native enzymes of milk were not affected when subjected to ultrasound.

\subsection{Spray drying using ultrasonic atomization}

Atomizing devices provide a high surface-to-mass ratio during the spray drying of dairy products, enabling rapid heat transfer and high evaporation rates. The two most common atomizing devices used in dairy applications are centrifugal (rotary) and pressure (nozzle) atomizers [25]. However, ultrasonic atomizers offer a viable alternative [58]. In this case, it is important to distinguish between ultrasonic nozzles that produce an aerosol by passing a liquid feed through a vibrating horn and ultrasonic nebulizers that operate at higher ultrasonic frequencies and generate a "fountain-like" structure in a thin liquid film. The droplet sizes produced by an ultrasonic nebulizer are an order of magnitude smaller than that which is available from an ultrasonic nozzle [78]. While ultrasonic spray driers containing nozzles are available for large-scale operations [7], ultrasonic nebulizers have not yet been developed for large-scale industrial use. Both devices have the technical advantage over classical spray-drying atomizers in that they produce a spray at a much lower velocity. This means that the spray chamber required for drying can be much smaller. While these devices would appear to offer much promise for spray-drying 
applications [3, 42, 59, 60, 62, 63, 79], a review of the literature was unable to locate an article describing this approach to dairy fluids.

\subsection{Ultrasonic crystallization and freezing (sonocrystallization)}

It has been observed in traditional methods of crystallization and freezing that a uniform size of crystals is difficult to obtain due to several factors including a lack of uniform nucleation, fluctuations in temperatures and pressures, ineffective cooling due to surface encrustation of cooling coils and non-uniform crystal growth due to uneven mixing. Acoustic cavitation can promote nucleation in a phenomenon referred to as sonocrystallization [102]. Further, the microstreaming and general turbulence associated with this process accelerate the heat and mass transfer associated with the freezing process. Finally, the shear forces present can break crystals as they form and hence result in a frozen product with much smaller crystal sizes. Ultrasound can thus accelerate the freezing process and lead to better product quality [102]. By controlling the sonication conditions, more uniform sized crystals can be produced.

A description of sonocrystallization as an industrial process has been provided by Mason [63]. De Castro and Priego-Capote [31] provide further information: for example, it is suggested that the rapid local cooling rates generated during acoustic cavitation reduce the crystallization temperature. McCausland and Cains [67] showed that the use of high-intensity, low-frequency ultrasound could enhance the extent of ice nucleation, reduce crystal induction time and cause a more uniform crystal growth. When ultrasound was applied at $\sim 70 \mathrm{kHz}$, cavitation bubbles were formed between the growing boundaries of ice crystals. Further observations were made of these bubbles causing melting due to their random motion [27]. Such random motion of cavitation bubbles on ice crystals broke down any ice dendrites that were formed (Fig. 6).

These results would suggest that ultrasound could be particularly effective in the preparation of ice-cream. Indeed, this approach has been patented by Acton and Morris [1]. The placement of ultrasonic transducers around the external surface of a scraped surface heat exchanger barrel prevented the encrustation of crystals on the cold surface and thus enhanced the heat transfer rate. This application may remove the requirement for mechanical scrapers ultrasound may act as an "acoustic scraper" [1]. However, ice-cream contains up to $50 \%$ by volume of air and this may mitigate against the use of ultrasound. Sonication is known as an effective degasser and this would affect the final texture of the icecream. Acton and Morris recommend either increasing the initial gas content or operating at elevated pressure to mitigate against these effects. These authors [1] also recommend the use of a tube sonicator upstream of the scraped surface exchanger as the ideal approach for ice-cream.

Bund and Pandit [23] found that sonication in an ultrasonic bath assembly $(22 \mathrm{kHz})$ of a $17.5 \%(\mathrm{w} / \mathrm{v})$ lactose solution (containing $85 \%(\mathrm{v} / \mathrm{v})$ ethanol at $\mathrm{pH} 4.2)$ enhanced the rate and efficiency of lactose crystallization. About $92 \%$ lactose was recovered in the presence of ultrasound compared to $15 \%$ recovery for unsonicated but mechanically (500 rpm) stirred samples (Fig. 7). This was caused by the cavitationassisted rapid lowering of vapor pressure of the solution due to the presence of ethanol, which reduced the solubility of lactose in the ethanol/water mixture.

It was shown with $15 \%$ sucrose solution [27] that microbubbles generated by cavitation acted as nucleation sites for ice formation (Fig. 8). This could also be the cause for the faster lactose crystallization observed by Bund and Pandit [23].

Bund and Pandit [23] showed that the size and shape characteristics of lactose 

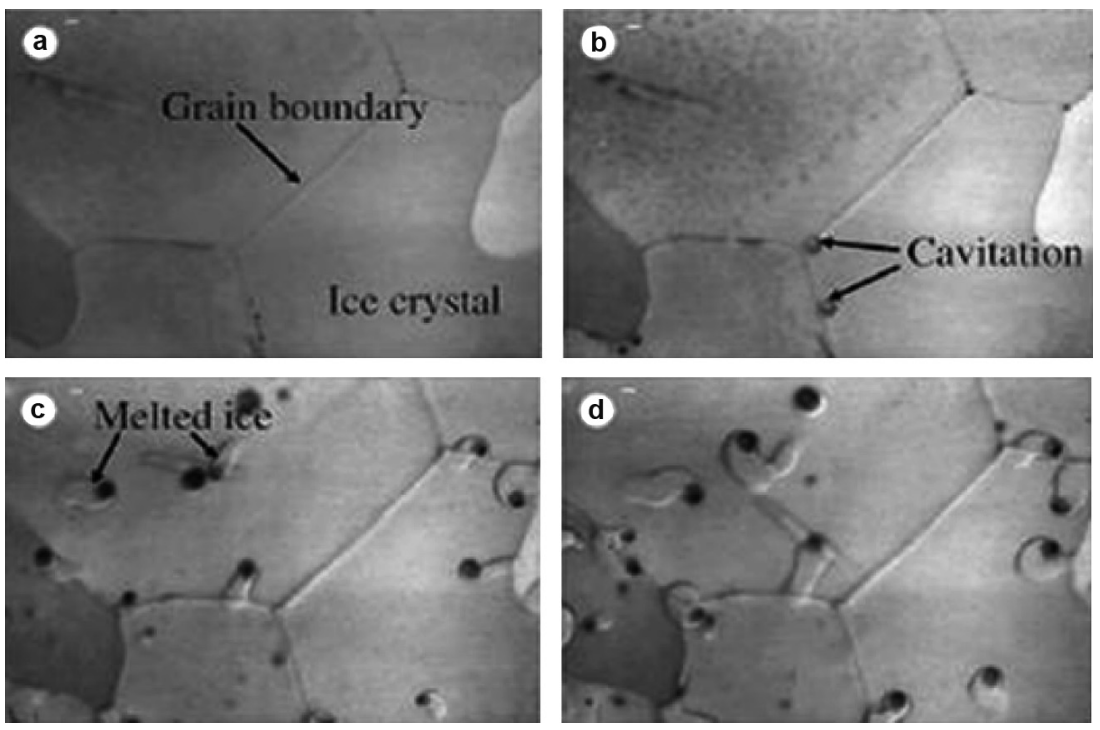

Figure 6. Effect of ultrasound on hexagonal ice crystals: (a) before ultrasound application, (b) ultrasound applied for $1 \mathrm{~s}$, showing cavitation bubbles, (c) ultrasound induced cavitation causing melt and (d) randomized motion of cavitation bubbles after another $0.5 \mathrm{~s}$. (Reprinted with permission from [27].)

crystals were also improved when sonication was applied. The effects of several experimental conditions on the lactose crystallization process and the lactose crystal properties were investigated: these included the initial lactose concentration, vapor pressure of solution, temperature, ultrasonic frequency, intensity and duration and the presence of inhibitors.

Dhumal et al. [32] used ultrasoundassisted in-situ seeding for controlling the crystal growth, shape and size of lactose crystals. They suggested that sonocrystallization caused spontaneous supersaturation of lactose, which accelerated the growth of the seeds lengthwise leading to the formation of rod-shaped crystals.

A similar study on fat globules in dairy systems showed a unique opportunity to balance crystallized and uncrystallized fat to alter the physicochemical characteristics of the product. Martini et al. [61] studied the effect of high-intensity ultrasound on fat crystallization and found that a faster crystallization could be achieved with smaller crystals. The samples showed increased viscosity after sonication due to crystallization.

\subsection{Modification of functional properties of dairy ingredients}

Several studies have shown that the physical effects of ultrasound can be used effectively to reduce the viscosity of food systems by disrupting aggregates and reducing the interaction between neighboring structures. For example, both Iida et al. [41] and Zuo et al. [103] have used cavitationinduced shear forces to modify the viscosity of starch solutions. A number of studies are also available on the use of the chemical effects that are generated during sonication for the modification of the functional properties of food ingredients [11, 40, 46, 47, 88].

In most cases, the modification of the physical properties of dairy systems by 


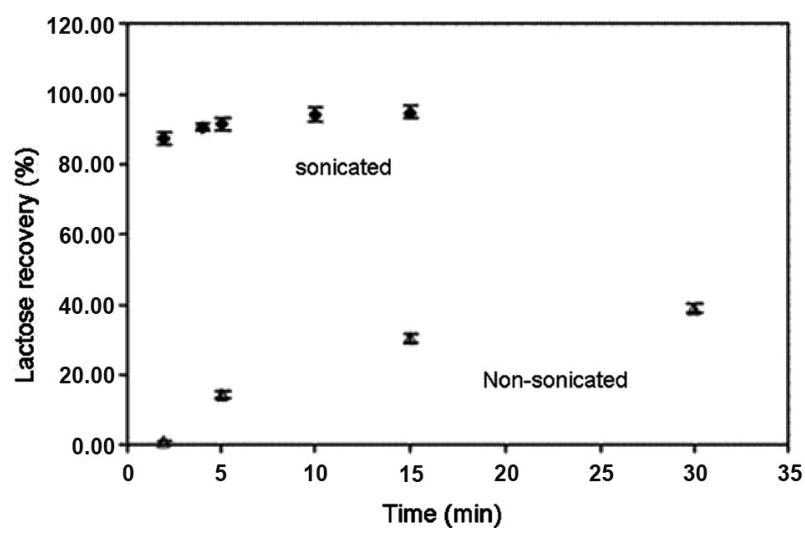

Figure 7. Lactose recovery in sonicated and unsonicated samples over time. (Reprinted with permission from [23].)
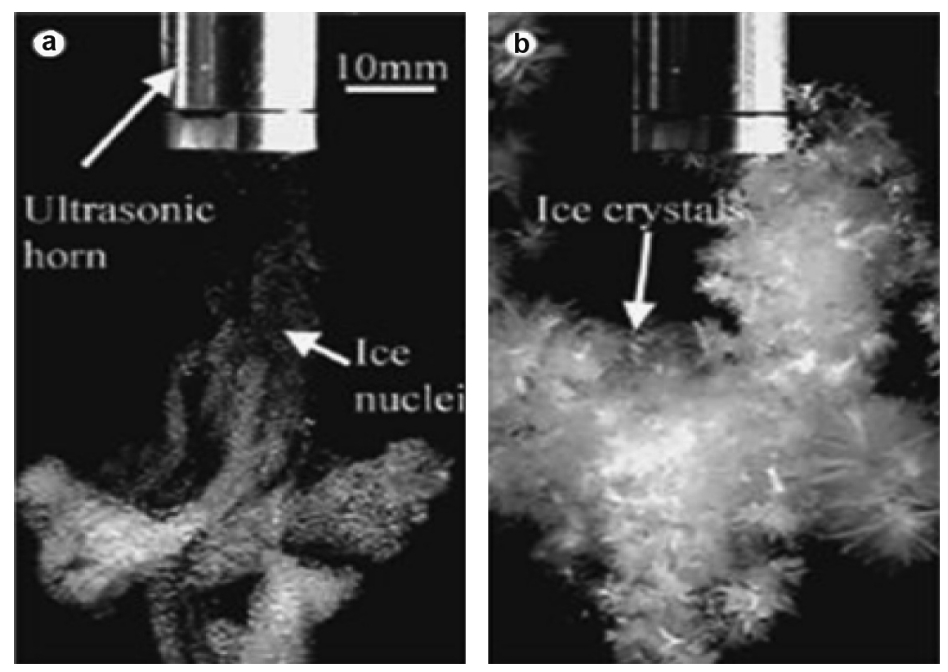

Figure 8. Ice crystals nucleated in a $15 \%(\mathrm{w} / \mathrm{w})$ sucrose solution at $-3.4{ }^{\circ} \mathrm{C}$ by a high-intensity ultrasound horn: (a) ice crystals following an ultrasonic pulse and (b) ice crystals formed after $5 \mathrm{~s}$ of applying ultrasound. (Adapted from [27].)

ultrasound can reasonably be attributed to the effect of shear forces alone. In the simplest case, Stone and Fryer [89] used an ultrasonic bath to disperse the aggregates of bacteria in refrigerated raw milk. Similarly, Taylor and Richardson [90] observed that sonication disrupted casein micelles to generate free casein in the solution. How- ever, the reactive sulfhydryl content of the milk was not affected. Kresic et al. [53] studied the effect of high pressure processing, ultrasonic treatment and tribomechanical activation (a rotor system that induces friction and collision between particles) on the rheological and thermophysical properties of whey proteins (whey protein 
concentrate [WPC] and whey protein isolate [WPI]). While the high pressure treatment decreased the water solubility of both WPC and WPI by about $10 \%$, both ultrasound and tribomechanics increased the water solubility of the whey proteins by about $5-6 \%$. The decrease in the water solubility due to high pressure treatment was suggested to be due to heat-induced denaturation of the proteins leading to aggregation. It has been suggested that the ultrasonic treatment changed the conformation of the proteins leading to the exposure of hydrophilic moieties (amino and carboxyl groups) to water. A similar explanation was provided for the increase in water solubility observed with tribomechanical action. The effects of these processing techniques on the rheological properties of the whey proteins are summarized in Table I.

A significant increase in viscosity by high pressure treatment was similarly explained by the loss of the tertiary structure of the globular proteins leading to an increase in the volume of the proteins. The more moderate increase in viscosity due to ultrasound and tribomechanical treatments was suggested to be due to increased water-holding capacity as a result of the exposure of hydrophilic moieties to water.

The initial freezing and thawing temperatures (thermophysical properties) of the whey proteins were found to be affected by all three processing techniques. High pressure treatment decreased the initial freezing and thawing temperatures by $\sim 1-2^{\circ} \mathrm{C}$, while ultrasound and tribomechanical activation processes decreased these temperatures by $0.5-1{ }^{\circ} \mathrm{C}$. These changes were linked to the physicochemical properties of the whey proteins as previously discussed. Further evidence supporting physicochemical protein changes was given by differential thermal analysis data.

Jambrak et al. [44] extended the abovementioned study by looking at the foaming properties of whey protein suspensions using both low-intensity high-frequency
Table I. The effects of different processing techniques on the rheological properties of WPC and WPI [53].

\begin{tabular}{lcr}
\hline $\begin{array}{l}\text { Processing } \\
\text { technique }\end{array}$ & \multicolumn{2}{c}{$\begin{array}{c}\text { Apparent viscosity, } \\
\mathrm{mPa} \cdot \mathrm{s}(\text { shear rate }\end{array}$} \\
\cline { 2 - 3 } & WPC & WPI \\
\hline Control & 7.0 & 7.0 \\
$\begin{array}{l}\text { High pressure } \\
(500 \mathrm{MPa}, 10 \mathrm{~min})\end{array}$ & 10.0 & 10.4 \\
$\begin{array}{l}\text { Ultrasound } \\
\left(20 \mathrm{kHz}, 50 \mathrm{~W} \cdot \mathrm{cm}^{-2}\right)\end{array}$ & 8.0 & 8.0 \\
$\begin{array}{l}\text { Tribomechanical } \\
\text { activation }\end{array}$ & 8.0 & 8.5 \\
\hline
\end{tabular}

$(500 \mathrm{kHz})$ and high-intensity low-frequency (20 and $40 \mathrm{kHz}$ ) ultrasound. While the highfrequency sonication did not affect the solubility significantly, the low-frequency treatment showed an increase in the solubility of the whey proteins as previously mentioned. Similarly, the foaming ability of whey protein suspensions was significantly enhanced by the low-frequency treatment. The sonication of whey proteins at high frequencies did not affect the foaming ability, suggesting that the chemical effects of cavitation did not play any role in altering the functional properties of whey proteins. This supports the suggestion [86] that the conformational changes to the protein structure caused by the physical forces of cavitation are responsible for the enhanced functional properties of whey proteins.

The effect of sonication on the mechanical strength of edible WPC film was investigated by Banerjee et al. [14]. An aqueous slurry containing 10\% WPC was sonicated at different frequencies for $30 \mathrm{~min}$. The ultrasonically treated slurry was then dried to form a thin film. The sonication at $520 \mathrm{kHz}$ increased the tensile strength by about 50\%, whereas 168 and $860 \mathrm{kHz}$ ultrasound did not improve the tensile strength of the film. However, in the same study it was observed that sonication significantly 


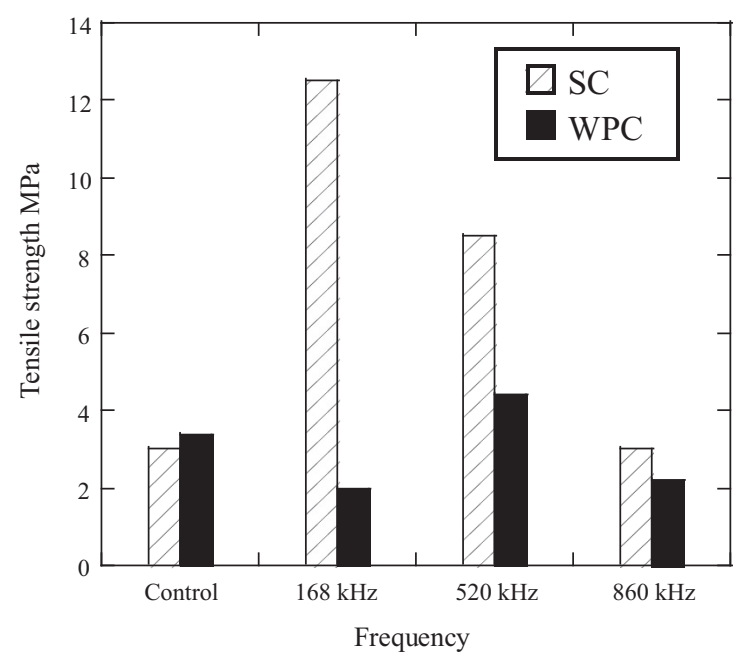

Figure 9. Effect of sonication on the tensile strength of edible films of SC and WPC; treatment time $=30$ min; power $=3-3.5 \mathrm{~W}$. (Adapted from Figure 2 of [14].)

enhanced the tensile strength of films made up of sodium caseinate (SC) at all three frequencies (Fig. 9).

The observed differences were related to the primary intermolecular forces that were involved in these two systems. Casein film is formed due to extensive hydrogen bonding, strong electrostatic and hydrophobic interactions, whereas whey protein binding involves disulfide (covalent) crosslinking. Further mechanistic details explaining the interactions between casein micelles as influenced by ultrasound were not discussed by the authors. The observation that the tensile strength of the casein system decreased with increasing frequency suggests that the changes are related to the physical effects of ultrasound. Since the interactions between casein units are physical interactions, the higher mechanical forces generated at a lower frequency were found to be effective. An increase in the tensile strength observed at $520 \mathrm{kHz}$ for WPC indicates that high-frequency ultrasound may have increased the disulfide linkage in the WPC film. However, the heating effect due to the sonication may also be the reason for the slight increase in the tensile strength: heat-induced aggregation/crosslinking is commonly observed in dairy proteins [68].

Our recent investigation [9] has shown that ultrasonic processing can significantly alter the water solubility, particle size distribution, viscosity, gel strength and syneresis of reconstituted whey protein suspensions. In Figure 10, it is shown that the transparency of a 5\% WPC solution was notably improved by sonication at $20 \mathrm{kHz}$. This improvement in solution clarity is due to the reduction in the particle size of the insoluble component of reconstituted WPC caused by the physical effects of ultrasound. Sonication at higher frequencies $(>200 \mathrm{kHz})$ did not show such an effect. Evidence to suggest that sonication disrupted larger insoluble aggregates of reconstituted WPC to generate smaller particles can be observed in the size distribution data shown in Figure 11. The size of reconstituted WPC aggregates prior to sonication was in the range $10-100 \mu \mathrm{m}$. Within the first $10 \mathrm{~min}$ of sonication, the intensity due to larger aggregates was completely reduced indicating the ultrasonic disruption of larger aggregates. Conversely, a band 


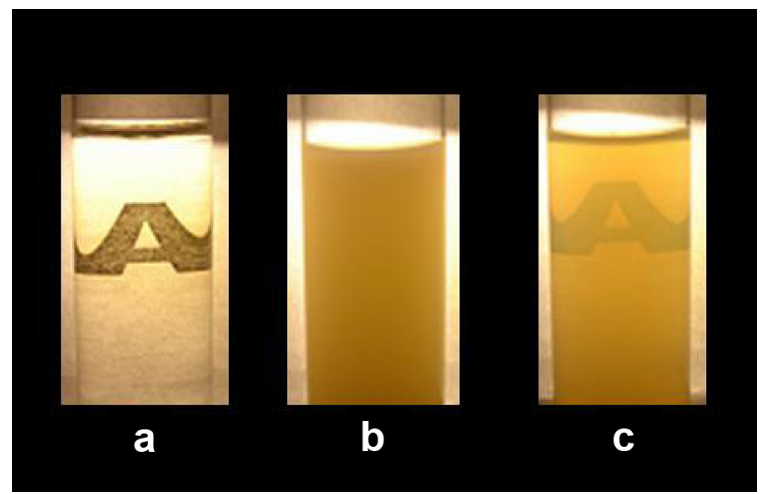

Figure 10. The clarity of $5 \%(\mathrm{w} / \mathrm{w})$ reconstituted WPC 80 solutions sonicated at $20 \mathrm{kHz}$ and $31 \mathrm{~W}$ : (a) water (the letter A could be clearly seen in the background), (b) 0 min sonication and (c) $60 \mathrm{~min}$ sonication.

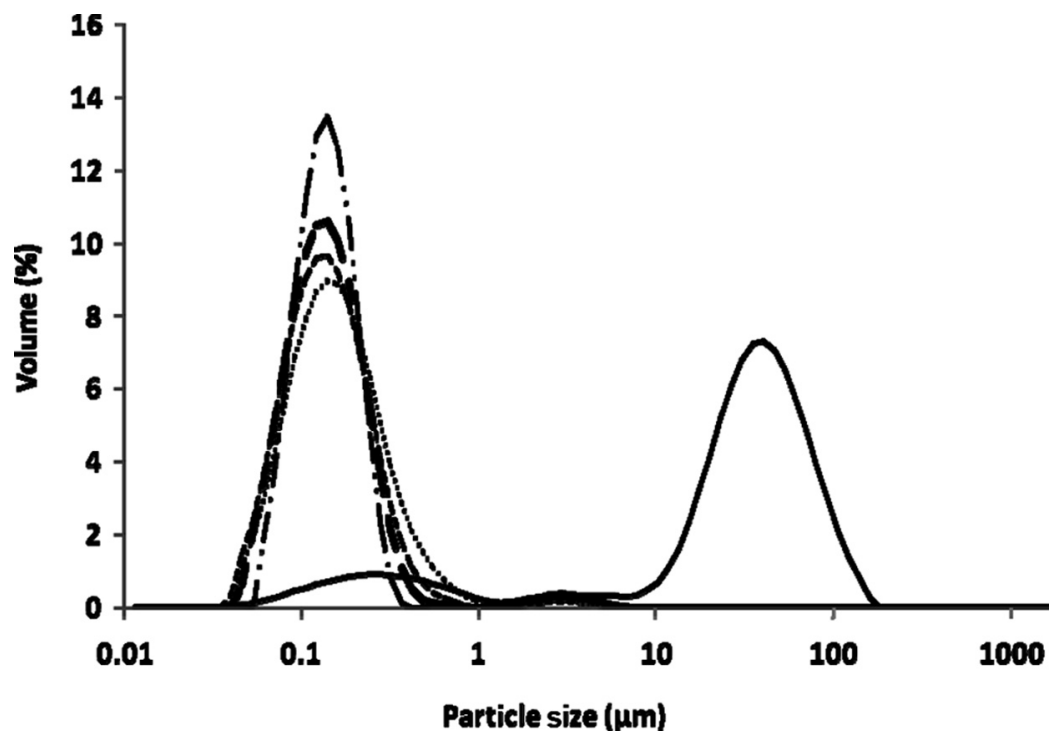

Figure 11. The particle size distribution (measured by a Malvern Master Sizer) of $5 \%(\mathrm{w} / \mathrm{w})$ reconstituted WPC80 solutions sonicated at $20 \mathrm{kHz}$ and $31 \mathrm{~W}$. No sonication (-), $10 \mathrm{~min}$ sonication (…), 20 min sonication (- - -), 40 min sonication (- - ) and 60 min sonication $(-\cdot)$.

corresponding to particles in the size range of $0.1 \mu \mathrm{m}$ continued to grow with increasing sonication time. It is speculated that the observed changes are due to the disruption of larger insoluble aggregates and not related to the solubility of the proteins since sonica- tion did not increase the UV-visible absorption band corresponding to the whey proteins. Further investigation is necessary to fully test this hypothesis.

The WPC suspension was heated after sonication in order to induce gelation and 

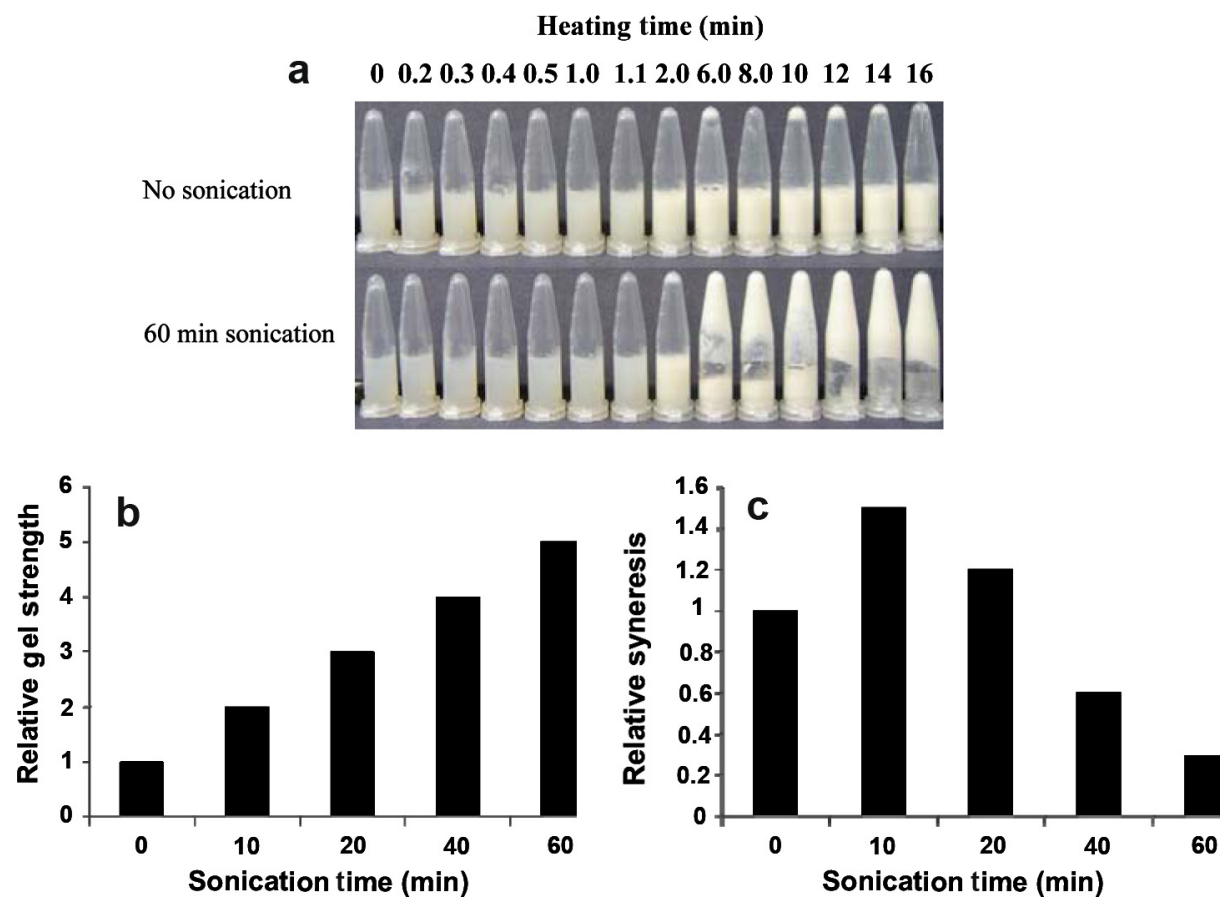

Figure 12. (a) Gelation point of $5 \%(\mathrm{w} / \mathrm{w})$ reconstituted WPC 80 solutions heated at $80{ }^{\circ} \mathrm{C}$ with or without sonication at $31 \mathrm{~W}$ and $20 \mathrm{kHz}$; (b) gel strength of $15 \%(\mathrm{w} / \mathrm{w})$ reconstituted WPC80 solutions sonicated at $20 \mathrm{kHz}$ and $31 \mathrm{~W}$ relative to the gel strength of non-sonicated solution: gel strength without sonication $=12.3 \mathrm{~g}$; and (c) syneresis of $15 \%(\mathrm{w} / \mathrm{w})$ reconstituted WPC80 sonicated at $20 \mathrm{kHz}$ and $31 \mathrm{~W}$ relative to the syneresis of non-sonicated solution: syneresis without sonication $=13 \%$.

the effects of sonication on gelation time, gel strength and syneresis were studied. The data shown in Figure 12 suggest that all these properties were affected by sonication. Figure 12a shows that sonicated WPC suspensions gelled after $6 \mathrm{~min}$ of heating at $80{ }^{\circ} \mathrm{C}$. Unsonicated WPC suspensions, however, showed an increase in viscosity but did not gel after $16 \mathrm{~min}$ of heating. The relative strength of the gel was found to be greater for the sonicated sample as shown in Figure $12 \mathrm{~b}$ and the gel strength was found to increase with increasing sonication time. Further to creating firmer gels, the water-holding capacity of the sonicated gels was also enhanced (Fig. 12c).
In order to explore the versatility of the ultrasonic processing technology, skim milk concentrate (SMC) from a dairy plant was also used. The sonication of medium heat SMC, age thickened by 24 hours storage, showed a significant reduction in viscosity (>60\% reduction) (Fig. 13). The greatest reduction in viscosity was achieved in 1 min sonication; longer sonication times did not reduce the viscosity further. Experiments carried out with fresh SMC showed $\sim 10 \%$ reduction in viscosity. These data clearly suggest that the ultrasonic processing can be effective in manipulating and improving the functional properties of a number of dairy ingredients. 


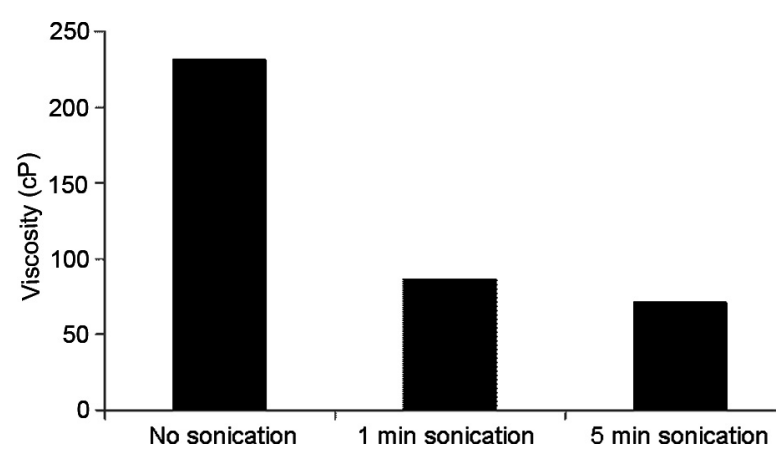

Figure 13. Viscosity of medium age thickened SMC at a shear rate of $100 \mathrm{~s}^{-1}$ batch sonicated at $20 \mathrm{kHz}$ and $31 \mathrm{~W}$ for 1 and $5 \mathrm{~min}$.

While manipulating the functional properties of dairy ingredients is interesting from the viewpoint of protein functionality, the actual mechanisms responsible for the observed effects are still under investigation. As mentioned earlier, sonication of a liquid generates a number of different effects: mechanical vibration, agitation, shear forces, turbulence, acoustic cavitation and chemically active free radicals. It is a difficult task to identify the key mechanisms that are involved in the ultrasound-induced changes to the functional properties of dairy ingredients. At this stage, it is speculated that functional changes are due primarily to the physical effects of acoustic cavitation altering protein structure, since a higher frequency ultrasound did not affect the functional properties of dairy ingredients.

\section{CONCLUSION}

The results of numerous research studies and a smaller but increasing number of successful commercial applications suggest that ultrasonics can be considered as an emerging technology of significant potential in many aspects of dairy processing. It has been suggested that the physical effects generated under cavitational and non-cavita- tional conditions are the main cause of the efficiency enhancements or functional property modifications observed in dairy systems. It is notable that many of these beneficial effects can be produced over short times and at low frequencies; conditions that negate or minimize some of the deleterious effects of ultrasound treatment, such as the generation of off-flavors. The preference for low-intensity treatments in many cases is also encouraging in terms of minimizing energy costs.

As ultrasonics is a relatively new field of endeavor in dairy research and development, the availability of industrial-scale - or even pilot-scale - ultrasonic processing equipment is still quite limited. This may hinder adoption of the technology in the short term, but experience with the development of ultrasonics technology in other industries (for example, homogenizers and spraydrying systems) suggests that this issue could readily be overcome once the economic advantages of ultrasound use are clearly demonstrated. In the dairy industry at present, the best opportunities for adoption of this technology would seem to be either as an adjunct process in an existing processing line or as a way of developing a new or improved functionality in a relatively low volume/high value dairy ingredient stream. 
Acknowledgements: The authors would like to acknowledge the financial support received from the Australian Research Council (ARC-LP LP0561887) and Dairy Innovation Australia Ltd. (Project 08105B). The authors thank Dr. Mary-Ann Augustin, Dr. Raymond Mawson and Prof. Franz Grieser for useful discussions.

\section{REFERENCES}

[1] Acton E., Morris G.J., Method and apparatus for the control of solidification in liquids, Worldwide Patent WO 9220420 (A1), 1992.

[2] Alexander M., Corredig M., Spectroscopic methods to determine in situ changes in dairy systems - ultrasonic and light scattering, Lait 87 (2007) 435-442.

[3] An G.H., Kim M.J., Lee H.J., Fabrication of Terazocin-loaded poly(D, L-lactide) microspheres by an ultrasonic spray drying method and their release behaviors, J. Nanosci. Nanotechnol. 8 (2008) 5139-5142.

[4] Anonymous, Alex Corporation, http://www. nalex.co.jp/e-cutter/e-foodcutter.html, Accessed 10 February 2009.

[5] Anonymous, Consonic Pty Ltd, http://www. consonic.com/branson-ultrasonic-cutting.html, Accessed 10 February 2009.

[6] Anonymous, Guide to Acid, Alkaline, Emulsion, and Ultrasonic Cleaning, American Society for Metals (ASM) International (Ed.), Russell Township, Ohio, USA, 1997.

[7] Anonymous, Sono-tek Corporation http:// www. sono-tek.com, Accessed 10 February 2009.

[8] Ashokkumar M., Grieser F., The effect of surface active solutes on bubbles in an acoustic field, Phys. Chem. Chem. Phys. 9 (2007) 5631-5643.

[9] Ashokkumar M., Kentish S.E., Lee J., Zisu B., Palmer M., Augustin M.A., Processing of dairy ingredients by ultra-sonication, $\mathrm{PCT}$ Int. Appl. WO 2009079691 A1, 2009.

[10] Ashokkumar M., Mason T., Sonochemistry, Kirk-Othmer Encyclopedia of Chemical Technology, John Wiley \& Sons, 2007, pp. 1-34.

[11] Ashokkumar M., Sunartio D., Kentish S.E., Mawson R., Simons L., Vilkhu K., Versteeg C., Modification of food ingredients by ultrasound to improve functionality, Innov. Food Sci. Emerg. Technol. 9 (2008) 155-160.
[12] Bakkali F., Moudden A., Faiz B., Amghar A., Maze G., Montero de Espinosa F., Akhnak M., Ultrasonic measurement of milk coagulation time, Meas. Sci. Technol. 12 (2001) 2154-2159.

[13] Balachandran S., Kentish S., Mawson R., Ashokkumar M., The use of ultrasound to enhance the supercritical extraction of ginger, Ultrason. Sonochem. 13 (2006) 471-479.

[14] Banerjee R., Chen H., Wu J., Milk protein based edible film mechanical strength changes due to ultrasound process, J. Food Sci. 61 (1996) 824-828.

[15] Benedito J., Carcel J., Clemente G., Mulet A., Cheese maturity assessment using ultrasonics, J. Dairy Sci. 83 (2000) 248-254.

[16] Benedito J., Carcel J., Gisbert M., Mulet A., Quality control of cheese maturation and defects using ultrasonics, J. Food Sci. 66 (2001) 100-104.

[17] Benedito J., Carcel J.A., Gonzalez R., Mulet A., Application of low intensity ultrasonics to cheese manufacturing processes, Ultrasonics 40 (2002) 19-23.

[18] Benedito J., Carcel J.A., Sanjuan N., Mulet A., Use of ultrasound to assess Cheddar cheese characteristics, Ultrasonics 38 (2000) 727-730.

[19] Benedito J., Simal S., Clemente G., Mulet A., Manchego cheese texture evaluation by ultrasonics and surface probes, Int. Dairy J. 16 (2006) 431-438.

[20] Bermúdez-Aguirre D., Barbosa-Cánovas G.V., Study of butter fat content in milk on the inactivation of Listeria innocua ATCC 51742 by thermo-sonication, Innov. Food Sci. Emerg. Technol. 9 (2008) 176-185.

[21] Bermúdez-Aguirre D., Corradini M.G., Mawson R., Barbosa-Cánovas G.V., Modeling the inactivation of Listeria innocua in raw whole milk treated under thermo-sonication, Innov. Food Sci. Emerg. Technol. 10 (2009) 172-178.

[22] Bermúdez-Aguirre D., Mawson R., Canovas G.V.B., Microstructure of fat globules in whole milk after thermosonication treatment, J. Food Sci. 73 (2008) E325-E332.

[23] Bund R.K., Pandit A.B., Sonocrystallization: effect on lactose recovery and crystal habit, Ultrason. Sonochem. 14 (2007) 143-152.

[24] Butz P., Tauscher B., Emerging technologies: chemical aspects, Food Res. Int. 35 (2002) 279-284. 
[25] Caric M., Milanovic S., Akkerman C., Kentish S.E., Tamime A.Y., Technology of evaporators, membrane processing and dryers, in: Tamime A. (Ed.), Dairy Powders \& Concentrated Products, Wiley VCH, Chichester, UK, 2009, pp. 99-148.

[26] Cho B.K., Irudayaraj J.M.K., A noncontact ultrasound approach for mechanical property determination of cheeses, J. Food Sci. 68 (2003) 2243-2247.

[27] Chow R., Blindt R., Kamp A., Grocutt P., Chivers R., The microscopic visualisation of the sonocrystallisation of ice using a novel ultrasonic cold stage, Ultrason. Sonochem. 11 (2004) 245-250.

[28] Chow R., Blindt R., Chivers R., Povey M., A study on the primary and secondary nucleation of ice by power ultrasound, Ultrason. 43 (2005) 227-230

[29] Chukwumah Y.C., Walker L.T., Verghese M., Bokanga M., Ogutu S., Alphonse K., Comparison of extraction methods for the quantification of selected phytochemicals in peanuts, J. Agric. Food Chem. 55 (2007) 285-290.

[30] Corredig M., Alexander M., Dalgleish D.G., The application of ultrasonic spectroscopy to the study of the gelation of milk components, Food Res. Int. 37 (2004) 557-565.

[31] de Castro L.M.D., Priego-Capote F., Ultrasound assisted crystallization (sonocrystallization), Ultrason. Sonochem. 14 (2007) 717-724.

[32] Dhumal R.S., Biradar S.V., Paradkar A.R., York P., Ultrasound assisted engineering of lactose crystals, Pharm. Res. 25 (2008) 2835-2844.

[33] Ertugay M.F., Sengul M., Sengul M., Effect of ultrasound treatment on milk homogenization and particle size distribution of fat, Turk. J. Vet. Anim. Sci. 28 (2004) 303-308.

[34] Eskelinen J.J., Alavuotunki A.P., Haeggstrom E., Alatossava T., Preliminary study of ultrasonic structural quality control of Swiss-type cheese, J. Dairy Sci. 90 (2007) 4071-4077.

[35] Federer A., Winder W.C., Ultrasonic energy attenuation in Cheddar cheese and the effect of ultrasound on the ripening process, J. Dairy Sci. 42 (1959) 902-902.

[36] Garcia M.A., Burgos J., Sanz B., Ordonez J.A., Effect of heat and ultrasonic waves on the survival of two strains of Bacillus subtilis, J. Appl. Bacteriol. 67 (1989) 619-628.
[37] Gunasekaran S., Ay C., Milk coagulation cut-time determination using ultrasonics, J. Food Process Eng. 19 (1996) 63-73.

[38] Herrmann T., Lynch B., Ultrasonic sealing of flexible pouches through contaminated sealing surfaces, ANTEC Conference Proceedings 61, 2003, pp. 2629-3235.

[39] Ho C.C., Zydney A.L., A combined pore blockage and cake filtration model for protein fouling during microfiltration, J. Coll. Int. Sci. 232 (2000) 389-399.

[40] Hoshino Y., Kawasaki T., Okahata Y., Effect of ultrasound on DNA polymerase reactions: monitoring on a $27-\mathrm{MHz}$ quartz crystal microbalance, Biomacromolecules 7 (2006) 682-685.

[41] Iida Y., Tuziuti T., Yasui K., Towata A., Kozuka T., Control of viscosity in starch and polysaccharide solutions with ultrasound after gelatinization, Innov. Food Sci. Emerg. Technol. 9 (2008) 140-146.

[42] Itatani K., Iwafune K.K., Howell F.S., Aizawa M., Preparation of various calciumphosphate powders by ultrasonic spray freeze-drying technique, Mat. Res. Bull. 35 (2000) 575-585.

[43] Jafari S.M., He Y., Bhandari B., Nanoemulsion production by sonication and microfluidization - a comparison, Int. J. Food Prop. 9 (2006) 475-485.

[44] Jambrak A.R., Mason T.J., Lelas V., Herceg Z., Herceg I.L., Effect of ultrasound treatment on solubility and foaming properties of whey protein suspensions, J. Food Eng. 86 (2008) 281-287.

[45] Jimmy B., Kentish S., Grieser F., Ashokkumar M., Ultrasonic nebulisation in aqueous solutions and the role of interfacial adsorption dynamics in surfactant enrichment, Langmuir 24 (2008) 10133-10137.

[46] Kamal H., Sabry G.M., Lotfy S., Abdallah N.M., Ulanski P., Rosiak J., Hegazy E.A., Controlling of degradation effects in radiation processing of starch, J. Macromol. Sci., Part A: Pure Appl. Chem. 44 (2007) 865-875.

[47] Kawasaki T., Hoshino Y., Ishizu Y., Mizushiro Y., Okahata Y., Control of hydrolysis and condensation activities of thermolysis by ultrasound irradiation, Chem. Lett. 34 (2005) 1602-1603.

[48] Kentish S.E., Wooster T., Ashokkumar M., Balachandran S., Mawson R., Simons L., The use of ultrasonics for nano-emulsion 
preparation, Innov. Food Sci. Emerg. Technol. 9 (2008) 170-175.

[49] Knorr D., Zenker M., Heinz V., Lee D.U., Applications and potential of ultrasonics in food processing, Trends Food Sci. Technol. 15 (2004) 261-266.

[50] Kobayashi T., Chai X., Fuji N., Ultrasound enhanced cross-flow membrane filtration, Sep. Purif. Technol. 17 (1999) 31-40.

[51] Kobayashi T., Kobayashi T., Fuji N., Effect of ultrasound on enhanced permeability during membrane water treatment, Jpn. J. Appl. Phys. 39 (2000) 2980-2981.

[52] Kobayashi T., Kobayashi T., Hosaka Y., Fuji N., Ultrasound enhanced membrane cleaning processes applied in water treatments: influence of sonic frequency on filtration treatments, Ultrasonics 41 (2003) 185-190.

[53] Kresic G., Lelas V., Jambrak A.R., Herceg Z., Brncic S.R., Influence of novel food processing technologies on the rheological and thermophysical properties of whey proteins, J. Food Eng. 87 (2008) 64-73.

[54] Lamminen M.O., Walker H.W., Weavers L.K., Mechanisms and factors influencing the ultrasonic cleaning of particle-fouled ceramic membranes, J. Membr. Sci. 237 (2004) 213-223.

[55] Lee H.O., Luan H.C., Daut D.G., Use of an ultrasonic technique to evaluate the rheological properties of cheese and dough, J. Food Eng. 16 (1992) 127-150.

[56] Lowe M.J.S., Ultrasonics, in: Braun S.G., Ewins D.J., Rao S.S. (Eds.), Encyclopedia of Vibration, vol. 3, Elsevier, Oxford, UK, 2002, pp. 1437-1441.

[57] Lin S.X.Q., Chen X.D., A laboratory investigation of milk fouling under the influence of ultrasound, Food Bioprod. Process. 85 (2007) 57-62.

[58] Luz P.P., Pires A.M., Serra O.A., A low cost ultrasonic spray dryer to produce spherical microparticles from polymeric matrices, Quimica Nova 30 (2007) 1744-1746.

[59] Luz P.P., Pires A.M., Serra O.A., Europium luminescent polymeric microspheres fabricated by spray drying process, J. Fluor. 18 (2008) 695-700.

[60] Martinac A., Filipovic-Grcic J., Perissutti B., Voinovich D., Pavelic Z., Spray-dried chitosan/ethylcellulose microspheres for nasal drug delivery: swelling study and evaluation of in vitro drug release properties, J. Microencapsul. 22 (2005) 549-561.
[61] Martini S., Suzuki A.H., Hartel R.W., Effect of high intensity ultrasound on crystallization behavior of anhydrous milk fat, J. Am. Oil Chem. Soc. 85 (2008) 621-628.

[62] Mason T.J., Industrial sonochemistry: potential and practicality, Ultrasonics 30 (1992) 192-196.

[63] Mason T.J., Developments in ultrasoundnon-medical, Prog. Biophys. Mol. Biol. 93 (2007) 166-175.

[64] Mason T.J., Paniwnyk L., Lorimar J.P., The uses of ultrasound in food technology, Ultrason. Sonochem. 3 (1996) S253-S260.

[65] Masuzawa N., Odhaira E., Attempts to shorten the time of lactic fermentation by ultrasonic irradiation, Jpn. J. Appl. Phys. 41 (2002) 3277-3278.

[66] Mawson R., Knoerzer K., A brief history of the application of ultrasonics in food processing, Conference proceedings, 19th International Congress on Acoustics, Madrid, Spain, http:/www.sea-acustica.es/ WEB_ICA_07/fchrs/papers/ult-09-004.pdf, Accessed $1 \overline{7}$ August 2009.

[67] McCausland L., Cains P., Sonocrystallization using ultrasound to improve crystallization products and processes, Chem. Ind. 5 May (2003) 15-17.

[68] Mounsey J.S., O’Kennedy B.T., Conditions limiting the influence of thiol-disulphide interchange reactions on the heat-induced aggregation kinetics of $\beta$-lactoglobulin, Int. Dairy J. 17 (2007) 1034-1042.

[69] Mulet A., Benedito J., Bon J., Rossello C., Ultrasonic velocity in Cheddar cheese as affected by temperature, J. Food Sci. 64 (1999) 1038-1041.

[70] Mulet A., Benedito J., Golas Y., Carcel J.A., Noninvasive ultrasonic measurements in the food industry, Food Rev. Int. 18 (2002) 123133.

[71] Muthukumaran S., Kentish S.E., Ashokkumar M., Stevens G.W., Mechanisms for the ultrasonic enhancement of dairy whey ultrafiltration, J. Membr. Sci. 258 (2005) 106-114.

[72] Muthukumaran S., Kentish S.E., Ashokkumar M., Stevens G.W., Application of ultrasound in membrane separation processes: a review, Rev. Chem. Eng. 22 (2006) 155-194.

[73] Muthukumaran S., Kentish S.E., Ashokkumar M., Vivekanand V., Mawson R., Power ultrasound offers an environmentally friendly approach to cleaning dairy UF membranes, Aust. J. Dairy Technol. 59 (2004) 193. 
[74] Muthukumaran S., Kentish S.E., Lalchandani S., Ashokkumar M., Mawson R., Stevens G.W., Grieser F., The optimisation of ultrasonic cleaning procedures for dairy fouled ultrafiltration membranes, Ultrason. Sonochem. 12 (2005) 29-35.

[75] Muthukumaran S., Kentish S.E., Stevens G.W., Ashokkumar M., Mawson R., Frequency effects in the application of ultrasound to dairy ultrafiltration, J. Food Eng. 81/82 (2007) 364 373.

[76] Muthukumaran S., Yang K., Seuren A., Kentish S., Ashokkumar M., Stevens G.W., Grieser F., The use of ultrasonic cleaning for ultrafiltration membranes in the dairy industry, Sep. Purif. Technol. 39 (2004) 99-107.

[77] Nelson J.H., Winder W.C., Further studies on the use of ultrasonic waves to accelerate the ripening rate of cheese, J. Dairy Sci. 37 (1954) 638-638.

[78] Niven R.W., Ip A.Y., Mittelman S., Prestrelski S.J., Arakawa T., Some factors associated with the ultrasonic nebulization of proteins, Pharm. Res. 12 (1995) 53-59.

[79] Pakowski Z., Modern methods of drying nanomaterials, Trans. Porous Media 66 (2007) 19-27.

[80] Paniwnyk L., Cai H., Albu S., Mason T.J., Cole R., The enhancement and scale up of the extraction of antioxidants from Rosmarinus officinalis using ultrasound, Ultrason. Sonochem. 16 (2009) 287-292.

[81] Patist A., Bates D., Ultrasonic innovations in the food industry: from the laboratory to commercial production, Innov. Food Sci. Emerg. Technol. 9 (2008) 147-154.

[82] Piyasena P., Mohareb E., McKellar R.C., Inactivation of microbes using ultrasound: a review, Int. J. Food Microbiol. 87 (2003) 207-216.

[83] Plastics Design Library, Staff Handbook of Plastics Joining, William Andrew Publishing/ Plastics Design Library, Norwich, USA, 1997.

[84] Riener J., Noci F., Cronin D.A., Morgan D.J., Lyng J.G., Characterisation of volatile compounds generated in milk by high intensity ultrasound, Int. Dairy J. 19 (2009) 269-272.

[85] Riera E., Gallego-Juarez J.A., Mason T.J., Airborne ultrasound for the precipitation of smokes and powders and the destruction of foams, Ultrason. Sonochem. 13 (2006) 107116.
[86] Sakakibara M., Wang D., Ikeda K., Suzuki K., Effect of ultrasonic irradiation on production of fermented milk with Lactobacillus delbrueckii, Ultrason. Sonochem. 1 (1994) S107-S110.

[87] Salo S., Wirtanen G., Ultrasonic cleaning applications in dairies - case studies on cheese moulds and milk transportation crates, Brit. Food J. 109 (2007) 31-42.

[88] Stojanovic J., Silva J.L., Influence of osmotic concentration, continuous high frequency ultrasound and dehydration on antioxidants, color and chemical properties of rabbit eye blueberries, Food Chem. 101 (2007) 898-906.

[89] Stone D.L., Fryer T.F., Disruption of bacterial clumps in refrigerated raw milk using an ultrasonic cleaning unit, N. Z. J. Dairy Sci. Technol. 19 (1984) 221-228.

[90] Taylor M.J., Richardson T., Antioxidant activity of skim milk: effect of sonication, J. Dairy Sci. 63 (1980) 1938-1942.

[91] Tho P., Manasseh R., Ooi A., Cavitation microstreaming patterns in single and multiple bubble systems, J. Fluid Mech. 576 (2007) 191-233.

[92] Villamiel M., de Jong P., Influence of highintensity ultrasound and heat treatment in continuous flow on fat, proteins, and native enzymes of milk, J. Agric. Food Chem. 48 (2000) 472-478.

[93] Villamiel M., van Hamersveld E.H., de Jong P., Review: effect of ultrasound processing on the quality of dairy products, Milchwissenschaft 54 (1999) 69-73.

[94] Villamiel M., Verdurmen R., de Jong P., Degassing of milk by high-intensity ultrasound, Milchwissenschaft 55 (2000) 123125.

[95] Vercet A., Lopez P., Burgos J., Inactivation of heat-resistant lipase and protease from Pseudomonas fluorescens by manothermosonication, J. Dairy Sci. 80 (1997) 29-36.

[96] Vercet A., Oria R., Marquina P., Crelier S., Buesa P.L, Rheological properties of yoghurt made with milk submitted to manothermosonication, J. Agric. Food Chem. 50 (2002) 6165-6171.

[97] Wan J., Mawson R., Ashokkumar M., Ronacher K., Coventry M.J., Roginski H., Versteeg K., Emerging processing technologies for functional foods, Aust. J. Dairy Technol. 60 (2005) 167-169. 
[98] Wang Q., Bulca S., Kulozik U., A comparison of low-intensity ultrasound and oscillating rheology to assess the renneting properties of casein solutions after UHT heat pre-treatment, Int. Dairy J. 17 (2007) 50-58.

[99] Winder W.C., Swanson A.M., Price W.V., The influence of ultrasonic sound waves on cheese ripening, J. Dairy Sci. 33 (1950) 399-399.

[100] Wu H., Hulbert G.J., Mount J.R., Effects of ultrasound on milk homogenization and fermentation with yogurt starter,
Innov. Food Sci. Emerg. Technol. 1 (2008) 211-218.

[101] Yasui K., Influence of ultrasonic frequency on multibubble sonoluminescence, J. Acoust. Soc. Am. 112 (2002) 1405-1413.

[102] Zheng L., Sun D., Innovative applications of power ultrasound during food freezing processes - a review, Trends Food Sci. Technol. 17 (2006) 16-23.

[103] Zuo J., Knoerzer K., Mawson R., Kentish S., Ashokkumar M., The pasting properties of sonicated waxy rice starch suspensions, Ultrason. Sonochem. 16 (2009) 462-468. 